\title{
Retrospective cohort mortality study of workers at an aircraft maintenance facility. I Epidemiological
} results

\author{
R Spirtas, P A Stewart, J S Lee, D E Marano, C D Forbes, D J Grauman, H M Pettigrew, \\ A Blair, R N Hoover, J L Cohen
}

\begin{abstract}
A retrospective cohort study of 14457 workers at an aircraft maintenance facility was undertaken to evaluate mortality associated with exposures in their workplace. The purpose was to determine whether working with solvents, particularly trichloroethylene, posed any excess risk of mortality. The study group consisted of all civilian employees who worked for at least one year at Hill Air Force Base, Utah, between 1 January 1952 and 31 December 1956. Work histories were obtained from records at the National Personnel Records Centre, St. Louis, Missouri, and the cohort was followed up for ascertainment of vital state until 31 December 1982 . Observed deaths among white people were compared with the expected number of deaths, based on the Utah white population, and adjusted for age, sex, and calendar period. Significant deficits occurred for mortality from all causes (SMR 92, 95\% confidence interval (95\% CI) 90-95), all malignant neoplasms (SMR 90, 95\% CI 83-97), ischaemic heart disease (SMR 93, 95\% CI 88-98), nonmalignant respiratory disease (SMR 87, 95\%
\end{abstract}

US National Cancer Institute, NIH

R Spirtas, P A Stewart, D J Grauman, H M Pettigrew, A Blair, $R$ N Hoover

Currently with the National Institute of Child Health and Human Development, NIH

R Spirtas

University of Utah

J S Lee, D E Marano

Currently with Industrial Health Inc

D E Marano

Westat Inc

C D Forbes

Currently with the General Accounting Office, US Congress

C D Forbes

Currently with the US Environmental Protection Agency

H M Pettigrew

ARC Professional Services

J L Cohen
CI 76-98), and accidents (SMR 61, 95\% CI 5270). Mortality was raised for multiple myeloma (MM) in white women (SMR 236, 95\% CI 87-514), non-Hodgkin's lymphoma (NHL) in white women (SMR 212, 95\% CI 102390 ), and cancer of the biliary passages and liver in white men dying after 1980 (SMR 358, 95\% CI 116-836). Detailed analysis of the 6929 employees occupationally exposed to trichloroethylene, the most widely used solvent at the base during the 1950 s and 1960 s, did not show any significant or persuasive association between several measures of exposure to trichloroethylene and any excess of cancer. Women employed in departments in which fabric cleaning and parachute repair operations were performed had more deaths than expected from MM and NHL. The inconsistent mortality patterns by sex, multiple and overlapping exposures, and small numbers made it difficult to ascribe these excesses to any particular substance. Hypothesis generating results are presented by a variety of exposures for causes of death not showing excesses in the overall cohort.

Hill Air Force Base, Utah, is one of several facilities in the United States operated by the Air Force Logistics Command to maintain and overhaul aircraft and missiles. In the mid-1970s, workers at the base expressed concern over potential health effects from chemical exposures as a result of adverse health symptoms reported by around 120 persons who had worked in one particular building at the base. A congressional hearing produced preliminary evidence of a raised proportion of deaths from neoplasms of lymphatic and haematopoietic tissue, especially multiple myeloma. ${ }^{1}$ After reviewing the problem in February 1980, the National Research Council's committee on toxicology suggested that a two phase epidemiological study be undertaken, a 
retrospective cohort mortality study followed by a case-control study of any cause of death shown to be excessive in this population relative to an appropriately chosen comparison population. Of general concern to the workers were cancer, disorders of the neurological system, and dysfunction of the reproductive system ${ }^{2}$ in relation to solvents used in aircraft maintenance operations. Particular concern was expressed regarding neoplasms of the lymphatic and haematopoietic system.

The United States National Cancer Institute, with financial support from the United States Air Force and technical support from the American Federation of Government Employees and the United States Air Force, undertook a retrospective cohort mortality study of workers at the base (1) to determine whether working at this aircraft maintenance facility was associated with an increased risk of death; (2) to evaluate in detail mortality risks associated with exposure to trichloroethylene; (3) to determine whether any raised risks for specific causes of death were associated with specific chemical exposures; and (4) to generate hypotheses for future research by evaluating the relation between various diseases and specific chemicals.

\section{Methods}

\section{COHORT DEFINITION}

The study group was composed of all civilian employees who worked for at least one year at Hill Air Force Base between 1 January 1952 and 31 December 1956. This cohort, numbering 14457 persons, was assembled from individual earnings records (IERs) at the civilian branch of the National Personnel Records Center (NPRC), St Louis, Missouri. The IERs, which contain demographic and employment information, were used to establish eligibility of study subjects and to obtain identifying data for the cohort. From a feasibility study of a sample of records drawn from NPRC it was determined that a cohort, consisting of all persons who worked for at least one year at the base between 1952 and 1956, would provide adequate numbers of persons and adequate time since first exposure to study the effect of occupational exposure to trichloroethylene. The IERs for employment before 1952 were stored at NPRC in one alphabetical file (not separated by specific base). Official personnel folders (OPFs) were obtained for $99.8 \%$ of all subjects (14 425 out of 14457 ) for the purpose of abstracting identifying information (name, date of birth, race, sex, etc) and complete work histories while employed at the base (job title, date started in that job, name of the department, and the corresponding department symbol for each job held at the base).

Vital state of cohort members was determined through a number of sources including the Social Security Administration (SSA), United States Office of Personnel Management files on civil servants, official personnel folders, veterans administration records, motor vehicle bureaux, national death index, ${ }^{3}$ and interviews of base personnel. Of 14066 white subjects (and persons of unknown race), 13692 $(97 \%)$ were successfully traced for vital state as of 31 December 1982. For persons who died during the study period, death certificates were obtained from state vital statistics offices. The underlying and contributory cause(s) of death were determined by a nosologist according to the rubrics of the International Classification of Diseases (ICD) in effect at the time of death. Causes of death were assigned ICDA-8 numerical codes for purposes of analysis. ${ }^{4}$

\section{ASSESSMENT OF EXPOSURES}

A detailed description of the procedures to assess exposures can be found in a companion paper. ${ }^{5}$ Briefly, two industrial hygienists (DEM, JSL) conducted walkthrough surveys of the base, interviewed long term employees, and reviewed industrial hygiene files, position descriptions, and other historical documents from the base to obtain information on departments (called organisations by the air force), job titles and tasks, numbers of employees, operations, chemicals used, monitoring results, and engineering controls. From the personnel files of cohort members, over 150000 job title and organisation combinations were abstracted and standardised for spelling and word order, reducing the job dictionary to roughly 43000 job and organisation combinations.

Trichloroethylene (TCE) was of particular interest in this study because it was an important solvent used at the base by many workers (nearly 45000 person-years of exposure). Special efforts were, therefore, made to evaluate exposures to TCE. Quantitative assessments of actual exposure levels could not be made. For each combination of job and organisation, an assessment was made as to whether it had frequent or infrequent peak exposures to TCE, or continuous, or intermittent low level exposures to TCE, or both. From these patterns of use, exposure indices were developed that reflected comparative differences in exposure. Many other solvents were used at the base and, where possible, they were qualitatively evaluated. As it was difficult to identify with confidence particular solvents used for some jobs, a category of "mixed solvents" was designated. Continuous or intermittent patterns of exposure to mixed solvents were identified and again exposure indices were developed that reflected comparative differences. The development of exposure indices for TCE and mixed solvents enabled analyses to be performed by cumulative and average exposures.

\section{ANALYTICAL METHODS}

Using the OCMAP ${ }^{6}$ analysis program, standardised 
mortality ratios (SMRs) and confidence intervals ${ }^{7}$ were calculated for selected causes of death for the entire cohort and for subgroups with likely exposure to chemicals. The starting date for follow up was 1 January 1953 or one year after the start of employment, whichever was later. Person-years at risk were accumulated for the cohort by race, sex, and five year age and calendar era categories. Non-cancer rates for 1950-60 were obtained by using rates for 1960. The observed number of deaths was divided by the expected number of deaths and multiplied by 100 to give the SMR; SMRs are presented in table 3 when more than two observed, or two expected deaths, or both occurred. Confidence intervals $(95 \%)$ around the SMRs were computed assuming that the observed numbers of deaths had a Poisson distribution. ${ }^{7}$ Persons presumably deceased (based on vital state information from SSA and other sources) but lacking a death certificate were counted in the unknown cause of death category and included in the tabulation of "all causes of death." The $\chi^{7}$ test for trend in SMRs across exposure categories was derived from the $\chi^{2}$ test for linear trend of Breslow et al. ${ }^{8}$

A regrouping of lymphoreticular neoplasms was done to create two further categories with common histological characteristics: (1) non-Hodgkin's lymphoma (NHL) composed of lymphosarcoma and reticulosarcoma (ICD 200) and other neoplasms of lymphoid tissue (ICD 202) and (2) multiple myeloma (MM) (ICD 203). Utah death rates for NHL and MM were generated by the designers of OCMAP specifically for our use in this study.

Mortality risks among white male and female workers were compared with the mortality experience for the white male and female populations living in the United States and the state of Utah. The larger United States population provides more stable rates, but the Utah population is more reflective of the lifestyle of the civilian workers in this cohort. Risks by estimated duration of exposure were assessed to evaluate exposure response relations for each of 25 categories of chemicals. Person-years of exposure were computed from date of first exposure, which could have been as early as 1939. All periods of employment at the base until 31 December 1982 were counted in determining person-years of exposure. All 25 categories of exposure were accounted for in exposure specific analyses. Person-years of follow up began one year from date of first exposure to a given chemical or on 1 January 1953, whichever was later. Analyses were also conducted by time since first exposure (latency).

For persons exposed to TCE and mixed solvents, SMRs were calculated by type of exposure (that is, frequent or infrequent peaks, continuous or intermittent low level exposures). Analyses by cumulative exposure were also performed, in which years of exposure were accumulated for each cohort member in the appropriate exposure category until the cumulative index exceeded the next higher cut off point. Each cohort member then remained in the highest attained category until leaving the study. Data were also analysed by time since first exposure, highest exposure, and average exposure.

Internal comparisons were made to reduce possible bias by socioeconomic or cultural differences between cohort members and the general population of Utah, and to determine whether raised SMRs were base wide or limited to specific exposure categories. This second method involved life table analyses with the procedure of Thomas and Gart, ${ }^{9}$ which adjusted for age at entry into follow up (within five year categories) and competing causes of death. The Thomas-Gart (TG) method was used in place of the SMR because the unexposed subgroup in the cohort had small numbers; this violates the assumption made in using SMRs that no variation exists in death rates in the comparison group. Using this general linear multiple logistic model, white men and women exposed to a given chemical were compared with those of the same race and sex never exposed to any chemical while employed at the base. Chi square statistics and associated levels of significance ( $p$ values) were generated. Further TG analyses were also computed for groups with 20 or more years since first exposure to particular chemicals.

\section{Results}

DESCRIPTIVE STATISTICS

White men constituted $65 \%(9400 / 14457)$ of the total cohort and $22 \%$ (3138) were white women. The numbers of non-white men (269) and women (122) were too small for analysis. Persons of unknown race ( 1061 men and 467 women) have been combined with white persons for purposes of statistical analysis. The combined group of white workers and persons of unknown race is called whites in this report. Because the overwhelming percentage of persons with known race were white $(98 \%$ men and $96 \%$ women) and because information on race is available (from the death certificate) for essentially all known deaths, persons of unknown race consist almost entirely of those still alive or with unknown state. Roughly three quarters of the cohort were born after 1909. Fifty five per cent of the cohort were born in Utah. For the 1970 general Utah white population, $70 \%$ were born in Utah. ${ }^{10}$

A total of 9860 study subjects $(68 \%)$ were known to be alive as of 31 December, $1982,9182(64 \%)$ were no longer working at the base, $678(5 \%)$ were alive and working at the base, and $3832(27 \%)$ persons were deceased. Follow up was highly successful, with vital state, as of 31 December 1982, known for over $97 \%$ of the cohort. Tracing was more successful for men $(99 \%)$ than women $(93 \%)$. 
Table 1 Cause specific SMRs and 95\% CIs adjusted for age, sex, and calendar period: white workers

\begin{tabular}{|c|c|c|c|}
\hline Cause of death (ICDA 8th revision code) & Obs & Exp† & $S M R \dagger(95 \% C I)$ \\
\hline All causes of death & 3832 & $4146 \cdot 0$ & $92^{\star \star}(90-95)$ \\
\hline Tuberculosis & 11 & $9 \cdot 1$ & $121(60-216)$ \\
\hline $\begin{array}{l}\text { All malignant neoplasms } \\
\text { Cancer of buccal cavity and pharynx }\end{array}$ & 641 & $712 \cdot 3$ & $90^{\star}(83-97)$ \\
\hline Cancer of buccal cavity and pharynx & 15 & $13 \cdot 6$ & $111(62-183)$ \\
\hline Cancer of digestive organs and peritoneum & 174 & $197 \cdot 2$ & $88(76-102)$ \\
\hline Cancer of oesophagus & 10 & $11 \cdot 2$ & $89(43-164)$ \\
\hline Cancer of stomach & 39 & $41 \cdot 9$ & $93(66-127)$ \\
\hline Cancer of large intestine & 56 & $65 \cdot 8$ & $85(64-111)$ \\
\hline Cancer of rectum & 12 & $16 \cdot 8$ & $71(37-125)$ \\
\hline Cancer of biliary passages and liver & 19 & $12 \cdot 3$ & $155(93-242)$ \\
\hline Biliary passages $\ddagger$ & 15 & $8 \cdot 7$ & $172(96-285)$ \\
\hline Liver, primary $\ddagger_{+}^{+}$ & 4 & $3 \cdot 6$ & $111(30-284)$ \\
\hline Cancer of pancreas & 33 & $42 \cdot 1$ & $78(54-110)$ \\
\hline Cancer of all other digestive organs & 5 & $7 \cdot 5$ & $67(22-156)$ \\
\hline Cancer of respiratory system & 141 & $145 \cdot 3$ & $97(82-115)$ \\
\hline Cancer of larynx & 4 & $5 \cdot 9$ & $68(18-173)$ \\
\hline Cancer of bronchus, trachea, lung & 137 & $136 \cdot 0$ & $101(85-119)$ \\
\hline Cancer of all other respiratory tissues & 0 & $3 \cdot 3$ & $0(0-113)$ \\
\hline Cancer of breast & 30 & $41 \cdot 4$ & $73(49-104)$ \\
\hline All uterine cancers & 14 & $14 \cdot 2$ & $99(54-166)$ \\
\hline Cancer of cervix uteri & 9 & $6 \cdot 5$ & $139(64-264)$ \\
\hline Cancer of other female genital organs & 14 & $13 \cdot 9$ & $101(55-169)$ \\
\hline Cancer of prostate & 51 & $63 \cdot 3$ & $81(60-106)$ \\
\hline Cancer of testes and other male genital organs & 4 & $3 \cdot 6$ & $112(30-285)$ \\
\hline Cancer of kidney and other urinary organs & 13 & $15 \cdot 6$ & $83(44-143)$ \\
\hline Cancer of bladder & 18 & $17 \cdot 6$ & $102(61-162)$ \\
\hline Malignant melanoma of skin & 14 & $11 \cdot 7$ & $120(66-201)$ \\
\hline Cancer of eye & 1 & $1 \cdot 1$ & - \\
\hline Cancer of central nervous system & 16 & $23 \cdot 7$ & $68(39-110)$ \\
\hline Cancer of thyroid gland and other endocrine organs & 1 & $4 \cdot 1$ & $25(1-137)$ \\
\hline Cancer of bone & 4 & $2 \cdot 8$ & $143(39-366)$ \\
\hline Cancer of all lymphatic and haematopoietic tissue & 87 & $85 \cdot 4$ & $102(82-126)$ \\
\hline Lymphosarcoma and reticulosarcoma & 21 & $19 \cdot 8$ & $106(66-162)$ \\
\hline Hodgkin's disease & 6 & $9 \cdot 4$ & $64(24-140)$ \\
\hline Leukaemia and aleukaemia & 26 & $33 \cdot 2$ & $78(51-115)$ \\
\hline Cancer of all other lymphopoietic tissue & 34 & $23 \cdot 2$ & $147^{\star}(102-205)$ \\
\hline Multiple myeloma & 20 & $11 \cdot 7$ & $170 \star(104-262)$ \\
\hline Non-Hodgkin's lymphoma & 32 & 23.9 & $134(91-189)$ \\
\hline All other malignant neoplasms & 44 & $56 \cdot 2$ & $78(57-105)$ \\
\hline Benign neoplasms & 15 & $11 \cdot 2$ & $134(75-221)$ \\
\hline Diabetes mellitus & 78 & $79 \cdot 1$ & $99(78-123)$ \\
\hline Cerebrovascular disease & 266 & $318 \cdot 0$ & $84^{\star \star}(74-94)$ \\
\hline All heart diseases & 1475 & $1590 \cdot 6$ & $93^{\star \star}(88-98)$ \\
\hline Rheumatic heart disease & 91 & $94 \cdot 7$ & $96(77-118)$ \\
\hline Ischaemic heart disease & 1274 & $1368 \cdot 1$ & $93 \star(88-98)$ \\
\hline Chronic disease of endocardium; other myocardial disease & 10 & $22 \cdot 0$ & $46 \star \star(22-84)$ \\
\hline Hypertension with heart disease & 16 & $22 \cdot 3$ & $72(41-117)$ \\
\hline All other heart disease & 84 & $111 \cdot 1$ & $76^{\star \star}(60-94)$ \\
\hline Hypertension without heart disease & 8 & $10 \cdot 2$ & $78(34-154)$ \\
\hline Non-malignant respiratory disease & 249 & $287 \cdot 5$ & $87^{\star}(76-98)$ \\
\hline Influenza and pneumonia & 80 & $109 \cdot 3$ & $73 \star \star(58-91)$ \\
\hline Bronchitis, emphysema, asthma & 94 & $99 \cdot 8$ & $94(76-115)$ \\
\hline Bronchitis & 14 & 18.9 & $74(41-124)$ \\
\hline Emphysema & 68 & $75 \cdot 4$ & $90(70-114)$ \\
\hline Asthma & 12 & $6 \cdot 2$ & $194^{\star}(100-339)$ \\
\hline Other non-malignant respiratory diseases & 75 & 83.9 & $89(70-112)$ \\
\hline Ulcer of stomach and duodenum & 28 & $27 \cdot 3$ & $102(68-148)$ \\
\hline Cirrhosis of liver & 69 & $77 \cdot 3$ & $89(69-113)$ \\
\hline Nephritis and nephrosis & 25 & $22 \cdot 1$ & $113(73-167)$ \\
\hline All external causes of death & 269 & $426 \cdot 1$ & $63^{\star \star}(56-71)$ \\
\hline Accidents & 181 & $297 \cdot 7$ & $61 * \star(52-70)$ \\
\hline Motor vehicle accidents & 78 & $130 \cdot 8$ & $60 \star \star(47-74)$ \\
\hline All other accidents & 103 & $166 \cdot 6$ & $62^{\star \star(51-75)}$ \\
\hline Suicides & 72 & 88.9 & $81(63-102)$ \\
\hline Homicides and other external causes & 16 & $20 \cdot 3$ & $79(45-128)$ \\
\hline All other causes of death & 438 & $567 \cdot 7$ & $77^{\star \star}(70-85)$ \\
\hline Unknown causes $(999 \cdot 9)$ & 270 & & \\
\hline
\end{tabular}

$\star \mathrm{p}<0.05 ; \star^{\star} \mathrm{p}<0.01$

+ Expected deaths include persons of unknown race. Utah state death rates were used as standard. SMRs and $95 \%$ CIs are presented only if number of observed or expected deaths $>2$.

$\ddagger$ Special categories created for this study. 


\section{ANALYSIS OF TOTAL COHORT}

Table 1 presents SMRs for white workers adjusted for age, sex, and calendar period, using Utah death rates as the standard. For 44 out of 65 causes of death the SMR was less than 100 indicating an overall favourable mortality experience for the cohort. Significant excesses only existed for cancer of all other lymphopoietic tissue (ICD codes 202-203, 208-209; SMR 147, 95\% CI 102-205), multiple myeloma (MM) (ICD code 203; SMR 170, 95\% CI 104-262), and for asthma (SMR 194, 95\% CI 100-339).

Statistically non-significant excesses (SMRs of at least 120) were found for cancers of the biliary passages and liver (SMR 155, 95\% CI 93-242), uterine cervix (SMR 139, 95\% CI 64-264), bone (SMR 143, 95\% CI 39-366), malignant melanoma of the skin (SMR 120, 95\% CI 66-201), non-Hodgkin's lymphoma (NHL) (SMR 134, 95\% CI 91-189), and benign neoplasms (SMR 134, 95\% CI 75-221). More than the expected numbers of deaths occurred for tuberculosis (SMR 121, 95\% CI 60-216).

The significant deficits occurred for all causes of death (SMR 92, 95\% CI 90-95), all malignant neoplasms (SMR 90, 95\% CI 83-97), cerebrovascular disease (SMR 84, 95\% CI 74-94), all heart diseases (SMR 93, 95\% CI 88-98), ischaemic heart disease (SMR 93, 95\% CI 88-98), chronic disease of the endocardium, and other myocardial insufficiency (SMR 46, 95\% CI 22-84), all other heart diseases (SMR 76, 95\% CI 60-94), non-malignant respiratory disease (SMR 87, 95\% CI 76-98), influenza and pneumonia (SMR 80, 95\% CI 58-91), all external causes of death (SMR 63, 95\% CI 56-71), accidents (SMR 61, 95\% CI 52-70), motor vehicle accidents (SMR 60, 95\% CI 47-74), all other accidents (SMR 62, 95\% CI 51-75), and all other causes of death (SMR 77, CI 95\% 70-85). Many causes of death had non-significantly depressed SMRs.

Patterns of risk for NHL, MM, cancer of the biliary passages and liver, and asthma were not consistent by categories of latency or duration of employment among men or women. When the results of female SMRs for NHL and MM were considered together, the resulting $\chi^{2}$ statistic $\left(\chi^{2} 3.85\right.$, $\mathbf{p}=0.05)$ showed a significant positive trend with duration.

Because of the well known effect of solvents on the central nervous system, ${ }^{11}$ a special effort was made to review deaths due to multiple sclerosis, Parkinson's disease, and amyotrophic lateral sclerosis (ALS). Since the only readily available rates for these specific diseases were aggregated for the entire United States for the 1968-78 period (unpublished data, National Cancer Institute), the SMRs could only be adjusted for age. Analysis of amyotrophic lateral sclerosis in white women produced the SMR of 321 (95\% CI 87821). Because death rates for ALS in women have been comparatively high in Davis and Weber counties $(\mathrm{U} t a h)^{12}$ where most of the people who work at the base reside, it is unlikely that the excess seen was due to chemical exposures at the base. No other neurological diseases showed an excess.

\section{ANALYSIS BY EXPOSURE TO TRICHLOROETHYLENE}

Tables 2-5 present data from the second aim of the study-namely, the evaluation of the association between exposure to TCE and specific causes of death. Tables 2 and 3 provide SMRs for selected causes of death for white men and women, ever exposed to TCE during their careers at Hill Air Force Base. Mortality from all causes combined was significantly depressed among men (SMR 92, 95\% CI 87-96) and women (SMR 82, 95\% CI 71-95), and several causes of death had significant deficits in SMRs. Although no significant excess risks occurred in either sex, non-significantly raised SMRs were found among men for cancers of the biliary passages and liver (SMR 196, 95\% CI 85-386) and asthma (SMR 244, 95\% CI 79-570), and among women for cancer of the cervix (SMR 224, 95\% CI 61-574) and cancer of the lymphatic and haematopoietic system (SMR 143, 95\% CI 58-295), particularly for NHL (SMR 286, 95\% CI 78-731). Tables 4 and 5 present SMRs for selected causes of death for TCE exposed workers by estimated cumulative exposure categories. Significant upward trends by cumulative exposure were found among men for the categories "all causes of death" and "emphysema". Among women exposed to TCE, a significant negative trend by cumulative exposure was found for all cancers combined. Analysis by average exposure found a significant upward trend only among men for the all causes of death category (no table presented). Analyses by type of exposure to TCE (frequent $v$ infrequent peak exposures, and continuous $v$ intermittent low level) did not show any significant patterns.

\section{ANALYSIS BY SPECIFIC DISEASES}

Tables 6 and 7 consider the third aim of the studynamely, further analyses of the raised SMRs found in the overall cohort by total exposure to specific chemicals. Both tables display relative risks from exposure to 25 selected chemicals used on the base, plus the categories any chemical, any solvent, never exposed to any chemical, and total cohort. Exposure categories are not mutually exclusive because many workers had multiple exposures.

\section{Multiple myeloma}

Non-significantly raised SMRs for MM occurred among men and women exposed to the general category of any chemical, any solvent, or mixed solvents, and among women never exposed to any 
Table 2 Cause specific SMRs and 95\% CIs adjusted for age and calendar period: white men exposed to TCE

\begin{tabular}{|c|c|c|c|}
\hline Cause of death (ICDA 8th revision code) & Obs & $\operatorname{Exp} \dagger$ & $S M R(95 \% C I)$ \\
\hline All causes of death & 1508 & $1647 \cdot 8$ & $92^{\star \star}(87-96)$ \\
\hline Tuberculosis & 0 & 3.7 & $0^{\star}(0-99)$ \\
\hline All malignant neoplasms & 248 & $268 \cdot 5$ & $92(81-105)$ \\
\hline Cancer of buccal cavity and pharynx & 5 & $5 \cdot 7$ & $88(29-206)$ \\
\hline Cancer of digestive organs and peritoneum & 74 & $74 \cdot 7$ & $99(78-124)$ \\
\hline Cancer of oesophagus & 6 & $5 \cdot 7$ & $106(39-230)$ \\
\hline Cancer of stomach & 14 & $16 \cdot 0$ & $88(48-147)$ \\
\hline Cancer of large intestine & 27 & $23 \cdot 3$ & $112(73-164)$ \\
\hline Cancer of rectum & 4 & $6 \cdot 3$ & $64(17-163)$ \\
\hline Cancer of biliary passages and liver & 8 & $4 \cdot 1$ & $196(85-386)$ \\
\hline Biliary passages $\ddagger$ & 6 & $2 \cdot 5$ & $238(87-519)$ \\
\hline Liver, primary $\ddagger$ & 2 & 1.6 & - \\
\hline Cancer of pancreas & 14 & 16.9 & $83(45-139)$ \\
\hline Cancer of all other digestive organs & 2 & $2 \cdot 8$ & $72(9-260)$ \\
\hline Cancer of respiratory system & 65 & 69.5 & $94(72-119)$ \\
\hline Cancer of larynx & 1 & $2 \cdot 9$ & $34(1-191)$ \\
\hline Cancer of bronchus, trachea, lung & 64 & $65 \cdot 1$ & $98(76-126)$ \\
\hline Cancer of all other respiratory tissues & 0 & 1.4 & - \\
\hline Cancer of prostate & 22 & $27 \cdot 6$ & $80(50-121)$ \\
\hline Cancer of testes and other male genital organs & 1 & $2 \cdot 0$ & - \\
\hline Cancer of kidney and other urinary organs & 8 & $6 \cdot 7$ & $120(52-237)$ \\
\hline Cancer of bladder & 10 & $7 \cdot 3$ & $137(65-251)$ \\
\hline Malignant melanoma of skin & 5 & $5 \cdot 2$ & $96(31-224)$ \\
\hline Cancer of eye & 0 & 0.5 & - \\
\hline Cancer of central nervous system & 9 & $10 \cdot 1$ & $89(41-170)$ \\
\hline Cancer of thyroid gland and other endocrine organs & 1 & 1.5 & - \\
\hline Cancer of bone & 3 & $1 \cdot 1$ & $263(54-767)$ \\
\hline Cancer of all lymphatic and haematopoietic tissue & 30 & $34 \cdot 6$ & $87(59-124)$ \\
\hline Lymphosarcoma and reticulosarcoma & 9 & $8 \cdot 0$ & $112(51-213)$ \\
\hline Hodgkin's disease & 4 & $4 \cdot 3$ & $93(25-237)$ \\
\hline Leukaemia and aleukaemia & 9 & $13 \cdot 1$ & $69(31-130)$ \\
\hline Cancer of all other lymphopoietic tissue & 8 & $9 \cdot 2$ & $87(38-172)$ \\
\hline Multiple myeloma $\ddagger$ & 5 & 4.5 & $111(36-259)$ \\
\hline Non-Hodgkin's lymphomał & 10 & $9 \cdot 8$ & $103(49-189)$ \\
\hline All other malignant neoplasms & 15 & $21 \cdot 2$ & $71(40-117)$ \\
\hline Benign neoplasms & 5 & $4 \cdot 3$ & $117(38-273)$ \\
\hline Diabetes mellitus & 26 & $27 \cdot 6$ & $94(62-138)$ \\
\hline Cerebrovascular disease & 84 & $101 \cdot 0$ & $83(66-103)$ \\
\hline All heart diseases & 618 & 640.6 & $97(89-104)$ \\
\hline Rheumatic heart disease & 34 & $33 \cdot 4$ & $102(71-142)$ \\
\hline Ischaemic heart disease & 551 & $561 \cdot 7$ & $98(90-107)$ \\
\hline Chronic disease of endocardium; other myocardial disease & 3 & $8 \cdot 0$ & $37(8-109)$ \\
\hline Hypertension with heart disease & 5 & $6 \cdot 8$ & $73(24-171)$ \\
\hline All other heart disease & 25 & $43 \cdot 0$ & $58 \star \star(38-86)$ \\
\hline Hypertension without heart disease & 1 & $3 \cdot 7$ & $27(1-149)$ \\
\hline Non-malignant respiratory disease & 104 & $118 \cdot 3$ & $88(72-107)$ \\
\hline Influenza and pneumonia & 27 & 39.5 & $68^{\star}(45-100)$ \\
\hline Bronchitis, emphysema, asthma & 40 & $43 \cdot 6$ & $92(66-125)$ \\
\hline Bronchitis & 7 & $8 \cdot 4$ & $84(34-172)$ \\
\hline Emphysema & 28 & $33 \cdot 6$ & $83(55-121)$ \\
\hline Asthma & 5 & $2 \cdot 1$ & $244(79-570)$ \\
\hline Other non-malignant respiratory diseases & 37 & 36.9 & $100(71-138)$ \\
\hline Ulcer of stomach and duodenum & 10 & $10 \cdot 9$ & $92(44-169)$ \\
\hline Cirrhosis of liver & 25 & $36 \cdot 3$ & $69(45-102)$ \\
\hline Nephritis and nephrosis & 8 & 8.6 & $93(40-184)$ \\
\hline All external causes of death & 128 & $205 \cdot 6$ & $62^{\star \star}(52-74)$ \\
\hline Accidents & 79 & $141 \cdot 1$ & $56 \star \star(44-70)$ \\
\hline Motor vehicle accidents & 33 & $61 \cdot 2$ & $54 \star \star(37-76)$ \\
\hline All other accidents & 46 & $79 \cdot 7$ & $58^{\star \star}(42-77)$ \\
\hline Suicides & 41 & $45 \cdot 5$ & $90(65-122)$ \\
\hline Homicides and other external causes & 8 & $10 \cdot 0$ & $80(35-158)$ \\
\hline All other causes of death & 161 & 216.5 & $74^{\star \star}(63-87)$ \\
\hline Unknown causes $(999 \cdot 9)$ & 93 & & \\
\hline
\end{tabular}

${ }^{\star} \mathrm{p}<0.05 ;{ }^{\star \star} \mathrm{p}<0.01$

†Expected deaths include persons of unknown race. Utah state death rates were used as standard. SMRs and $95 \%$ CIs were presented only if number of observed or expected deaths $>2$.

+ Special categories created for this study. 
Table 3 Cause specific SMRs and 95\% CIs adjusted for age and calendar period: white women exposed to TCE

\begin{tabular}{|c|c|c|c|}
\hline Cause of death (ICDA 8th revision code) & Obs & $\operatorname{Exp} \dagger$ & $S M R(95 \% C I)$ \\
\hline All causes of death & 186 & $227 \cdot 2$ & $82^{\star \star}(71-95)$ \\
\hline Tuberculosis & 0 & 0.2 & - \\
\hline $\begin{array}{l}\text { All malignant neoplasms } \\
\text { Cancer of buccal cavity and pharynx }\end{array}$ & 33 & $49 \cdot 4$ & $67 \star(46-94)$ \\
\hline Cancer of buccal cavity and pharynx & 0 & 0.6 & - \\
\hline Cancer of digestive organs and peritoneum & 7 & $13 \cdot 0$ & $54(22-111)$ \\
\hline Cancer of oesophagus & 0 & $0 \cdot 2$ & - \\
\hline Cancer of stomach & 0 & $2 \cdot 0$ & - \\
\hline Cancer of large intestine & 2 & $5 \cdot 5$ & $37(4-132)$ \\
\hline Cancer of rectum & 1 & $1 \cdot 1$ & - \\
\hline Cancer of biliary passages and liver & 2 & $1 \cdot 2$ & - \\
\hline Biliary passages + & 2 & $1 \cdot 1$ & - \\
\hline Liver, primary $+_{+}^{-}$ & 0 & $0 \cdot 2$ & - \\
\hline Cancer of pancreas & 2 & $2 \cdot 5$ & $81(10-291)$ \\
\hline Cancer of all other digestive organs & 0 & 0.5 & - \\
\hline Cancer of respiratory system & 0 & $3 \cdot 1$ & $0(0-121)$ \\
\hline Cancer of larynx & 0 & $0 \cdot 1$ & - \\
\hline Cancer of bronchus, trachea, lung & 0 & $2 \cdot 8$ & $0(0-131)$ \\
\hline Cancer of all other respiratory tissues & 0 & 0.2 & - \\
\hline Cancer of breast & 9 & 11.5 & $79(36-149)$ \\
\hline All uterine cancers & 4 & $4 \cdot 1$ & $98(27-251)$ \\
\hline Cancer of cervix uteri & 4 & 1.8 & $224(61-574)$ \\
\hline Cancer of other female genital organs & 4 & $4 \cdot 0$ & $100(27-255)$ \\
\hline Cancer of kidney and other urinary organs & 0 & 0.8 & - \\
\hline Cancer of bladder & 1 & $0 \cdot 6$ & - \\
\hline Malignant melanoma of skin & 1 & $0 \cdot 6$ & - \\
\hline Cancer of eye & 0 & $0 \cdot 1$ & - \\
\hline Cancer of central nervous system & 0 & 1.4 & - \\
\hline Cancer of thyroid gland and other endocrine organs & 0 & 0.4 & - \\
\hline Cancer of bone & 0 & $0 \cdot 1$ & - \\
\hline Cancer of all lymphatic and haematopoietic tissues & 7 & $4 \cdot 9$ & $143(58-295)$ \\
\hline Lymphosarcoma and reticulosarcoma & 3 & $1 \cdot 2$ & $261(54-761)$ \\
\hline Hodgkin's disease & 0 & $0 \cdot \overline{3}$ & - \\
\hline Leukaemia and aleukaemia & 2 & $1 \cdot 9$ & - \\
\hline Cancer of all other lymphopoietic tissue & 2 & 1.5 & - \\
\hline Multiple myeloma + & 1 & 0.8 & - \\
\hline Non-Hodgkin's lymphoma + & 4 & $1 \cdot 4$ & $286(78-731)$ \\
\hline All other malignant neoplasms & 0 & $4 \cdot 2$ & $0 \star(0-86)$ \\
\hline Benign neoplasms & 2 & 0.8 & - \\
\hline Diabetes mellitus & 6 & $6 \cdot 8$ & $88(32-191)$ \\
\hline Cerebrovascular disease & 22 & $26 \cdot 6$ & $83(52-125)$ \\
\hline All heart diseases & 70 & $78 \cdot 7$ & $89(69-112)$ \\
\hline Rheumatic heart disease & 8 & $8 \cdot 6$ & $93(40-184)$ \\
\hline Ischaemic heart disease & 54 & $60 \cdot 2$ & $90(67-117)$ \\
\hline Chronic disease of endocardium; other myocardial disease & 1 & 1.5 & - \\
\hline Hypertension with heart disease & 1 & $2 \cdot 0$ & - \\
\hline All other heart disease & 6 & $7 \cdot 4$ & $82(30-178)$ \\
\hline Hypertension without heart disease & 0 & 0.7 & - \\
\hline Non-malignant respiratory disease & 4 & $10 \cdot 6$ & $38^{\star}(10-97)$ \\
\hline Influenza and pneumonia & 0 & $6 \cdot 3$ & $0 \star \star(0-59)$ \\
\hline Bronchitis, emphysema, asthma & 2 & $2 \cdot 1$ & $95(12-343)$ \\
\hline Bronchitis & 0 & 0.5 & - \\
\hline Emphysema & 2 & $1 \cdot 0$ & - \\
\hline Asthma & 0 & 0.5 & - \\
\hline Other non-malignant respiratory diseases & 2 & 2.5 & $80(10-287)$ \\
\hline Ulcer of stomach and duodenum & 0 & $1 \cdot 1$ & - \\
\hline Cirrhosis of liver & 3 & 3.4 & $88(18-257)$ \\
\hline Nephritis and nephrosis & 1 & $1 \cdot 3$ & - \\
\hline All external causes of death & 9 & $13 \cdot 0$ & $69(32-131)$ \\
\hline Accidents & 7 & 9.8 & $71(29-147)$ \\
\hline Motor vehicle accidents & 5 & $4 \cdot 7$ & $106(34-247)$ \\
\hline All other accidents & 2 & $5 \cdot 2$ & $39(5-140)$ \\
\hline Suicides & 2 & $2 \cdot 0$ & $99(12-357)$ \\
\hline Homicides and other external causes & 0 & 0.7 & - \\
\hline All other causes of death & 17 & $34 \cdot 2$ & $50 \star \star(29-80)$ \\
\hline Unknown causes (999.9) & 20 & & \\
\hline
\end{tabular}

${ }^{\star} \mathrm{p}<0.05 ;{ }^{\star \star} \mathrm{p}<0.01$.

+Expected deaths include persons of unknown race. Utah state death rates were used as standard. SMRs and $95 \%$ CIs are presented only if number of observed or expected deaths $>2$.

$\ddagger$ Special categories created for this study. 
Table 4 SMRs (Obs/Exp) for selected causes of death among white men by cumulative exposure to TCE

\begin{tabular}{|c|c|c|c|c|c|}
\hline \multirow[b]{2}{*}{ Cause } & \multicolumn{3}{|l|}{ Cumulative exposure } & \multirow{2}{*}{$\begin{array}{l}\text { Total } \\
\text { exposure }\end{array}$} & \multirow{2}{*}{$\begin{array}{l}\chi \text { for } \\
\text { trend } \dagger\end{array}$} \\
\hline & $<5$ & $5-25$ & $>25$ & & \\
\hline All causes & $87^{\star \star}(562 / 649 \cdot 2)$ & $88^{\star}(341 / 386 \cdot 3)$ & $99(605 / 612 \cdot 3)$ & $92^{\star}(1508 / 1647 \cdot 8)$ & $2 \cdot 48^{\star}$ \\
\hline All cancers & $94(99 / 105 \cdot 6)$ & $87(56 / 64 \cdot 1)$ & $94(93 / 98 \cdot 8)$ & $92(248 / 268 \cdot 5)$ & $0 \cdot 12$ \\
\hline Buccal/pharynx & $89(2 / 2 \cdot 3)$ & $-(0 / 1 \cdot 3)$ & $144(3 / 2 \cdot 1)$ & $88(5 / 5 \cdot 7)$ & 0.64 \\
\hline Biliary passages $\ddagger$ & $200(2 / 1 \cdot 0)$ & $500^{\star}(3 / 0 \cdot 6)$ & $106(1 / 0.9)$ & $236(6 / 2 \cdot 5)$ & -0.67 \\
\hline Primary liver cancer + & $324(2 / 0 \cdot 6)$ & $-(0 / 0 \cdot 4)$ & $-(0 / 0 \cdot 6)$ & $127(2 / 1 \cdot 6)$ & $\S$ \\
\hline Pancreas & $90(6 / 6 \cdot 7)$ & $75(3 / 4 \cdot 0)$ & $81(5 / 6 \cdot 2)$ & $83(14 / 16.9)$ & $-0 \cdot 18$ \\
\hline Lung & $96(25 / 26 \cdot 0)$ & $88(14 / 15 \cdot 9)$ & $107(25 / 23 \cdot 3)$ & $98(64 / 65 \cdot 1)$ & 0.42 \\
\hline Prostate & $68(7 / 10 \cdot 3)$ & $48(3 / 6 \cdot 2)$ & $109(12 / 11 \cdot 1)$ & $80(22 / 27 \cdot 6)$ & $1 \cdot 12$ \\
\hline Testes & $119(1 / 0 \cdot 8)$ & $-(0 / 0 \cdot 5)$ & $-(0 / 0 \cdot 7)$ & $50(1 / 2 \cdot 0)$ & - \\
\hline Kidney & $191(5 / 2 \cdot 6)$ & $-(0 / 1 \cdot 6)$ & $124(3 / 2 \cdot 4)$ & $120(8 / 6 \cdot 7)$ & -0.57 \\
\hline Bladder & $142(4 / 2 \cdot 8)$ & $177(3 / 1 \cdot 7)$ & $107(3 / 2 \cdot 8)$ & $136(10 / 7 \cdot 3)$ & $-0 \cdot 38$ \\
\hline CNS & $73(3 / 4 \cdot 1)$ & $163(4 / 2 \cdot 5)$ & $57(2 / 3.5)$ & $89(9 / 10 \cdot 1)$ & $-0 \cdot 19$ \\
\hline All lymphatic and haematopoietic tissue & $73(10 / 13 \cdot 8)$ & $61(5 / 8 \cdot 3)$ & $119(15 / 12 \cdot 6)$ & $87(30 / 34 \cdot 6)$ & $1 \cdot 26$ \\
\hline Leukaemia & $58(3 / 5 \cdot 2)$ & $-(0 / 3 \cdot 2)$ & $124(6 / 4 \cdot 8)$ & $69(9 / 13 \cdot 1)$ & $1 \cdot 34$ \\
\hline Multiple myeloma & $114(2 / 1 \cdot 8)$ & $95(1 / 1 \cdot 1)$ & $119(2 / 1 \cdot 7)$ & $111(5 / 4 \cdot 5)$ & 0.03 \\
\hline Non-Hodgkin's lymphoma & $128(5 / 3.9)$ & $129(3 / 2 \cdot 3)$ & $57(2 / 3.5)$ & $103(10 / 9 \cdot 8)$ & -0.91 \\
\hline Ischaemic heart disease & $94(207 / 219 \cdot 5)$ & $94(123 / 131 \cdot 2)$ & $105(221 / 211 \cdot 1)$ & $98(551 / 561 \cdot 7)$ & $1 \cdot 12$ \\
\hline Emphysema & $31^{\star \star}(4 / 12 \cdot 8)$ & $90(7 / 7 \cdot 8)$ & $131(17 / 12 \cdot 9)$ & $83(28 / 33 \cdot 6)$ & $2 \cdot 82^{\star}$ \\
\hline Asthma & $129(1 / 0 \cdot 8)$ & $423(2 / 0 \cdot 5)$ & $250(2 / 0 \cdot 8)$ & $244(5 / 2 \cdot 1)$ & 0.33 \\
\hline Cirrhosis of liver & $47^{\star}(7 / 14 \cdot 9)$ & $55(5 / 9 \cdot 1)$ & $105(13 / 12 \cdot 3)$ & $69(25 / 36 \cdot 3)$ & $1 \cdot 82$ \\
\hline Nephritis & $58(2 / 3 \cdot 4)$ & $102(2 / 2 \cdot 0)$ & $126(4 / 3 \cdot 2)$ & $93(8 / 8 \cdot 6)$ & $0 \cdot 88$ \\
\hline
\end{tabular}

${ }^{\star} \mathrm{p}<0.05 ;{ }^{\star \star} \mathrm{p}<0.01$.

Cumulative exposure categories were derived by cumulatively multiplying the exposure index assigned to each job by time exposed at that level (see Stewart $e t$ al $l^{5}$ for a detailed explanation of the derivation).

tDerived from $\chi^{2}$ test for linear trend. ${ }^{8}$

+ Special categories created for this study.

$\$ \chi$ not computed if number of observed deaths $<5$.

Table 5 SMRs (Obs/Exp) for selected causes of death among white women by cumulative exposure to trichloroethylene

\begin{tabular}{|c|c|c|c|c|c|}
\hline \multirow[b]{2}{*}{ Cause } & \multicolumn{3}{|c|}{ Cumulative exposure } & \multirow{2}{*}{$\begin{array}{l}\text { Total } \\
\text { exposure }\end{array}$} & \multirow{2}{*}{$\begin{array}{l}\chi \text { for } \\
\text { trend }\end{array}$} \\
\hline & $<5$ & $5-25$ & $>25$ & & \\
\hline All causes & $78(35 / 44 \cdot 7)$ & $60^{\star}(18 / 29 \cdot 9)$ & $87(133 / 152 \cdot 5)$ & $82^{\star}(186 / 227 \cdot 2)$ & 0.90 \\
\hline All cancer & $88(10 / 11 \cdot 4)$ & $43(3 / 7 \cdot 0)$ & $64^{\star}(20 / 31 \cdot 1)$ & $67 \star(33 / 49 \cdot 4)$ & $-2 \cdot 94^{\star}$ \\
\hline Buccal/pharynx & $-(0 / 0 \cdot 1)$ & $-(0 / 0 \cdot 1)$ & $-(0 / 0 \cdot 4)$ & $-(0 / 0 \cdot 6)$ & - \\
\hline Biliary passages $\ddagger$ & $435(1 / 0 \cdot 2)$ & $-(0 / 0 \cdot 1)$ & $143(1 / 0 \cdot 7)$ & $189(2 / 1 \cdot 1)$ & - \\
\hline Primary liver cancer + & $-(0 / 0 \cdot 0)$ & $-(0 / 0 \cdot 0)$ & $-0 / 0 \cdot 1)$ & $-(0 / 0 \cdot 2)$ & - \\
\hline Pancreas & $-(0 / 0.5)$ & $-(0 / 0 \cdot 3)$ & $125(2 / 1 \cdot 6)$ & $81(2 / 2 \cdot 5)$ & - \\
\hline Lung & $-(0 / 0 \cdot 7)$ & $-(0 / 0 \cdot 4)$ & $-(0 / 1 \cdot 7)$ & $-(0 / 2 \cdot 8)$ & - \\
\hline Breast & $107(3 / 2 \cdot 8)$ & $119(2 / 1 \cdot 7)$ & $57(4 / 7 \cdot 0)$ & $79(9 / 11.5)$ & -0.89 \\
\hline Kidney & $-(0 / 0 \cdot 2)$ & $-(0 / 0 \cdot 1)$ & $-(0 / 0 \cdot 5)$ & $-(0 / 0 \cdot 8)$ & - \\
\hline Bladder & $-(0 / 0 \cdot 1)$ & $-(0 / 0 \cdot 1)$ & $265(1 / 0.4)$ & $183(1 / 0 \cdot 6)$ & - \\
\hline CNS & $-(0 / 0 \cdot 4)$ & $-(0 / 0 \cdot 2)$ & $-(0 / 0 \cdot 8)$ & $-(0 / 1 \cdot 4)$ & - \\
\hline All lymphatic and haematopoietic tissue & $277(3 / 1 \cdot 1)$ & $-(0 / 0 \cdot 7)$ & $128(4 / 3 \cdot 1)$ & $143(7 / 4 \cdot 9)$ & -0.93 \\
\hline Leukaemia & $240(1 / 0 \cdot 4)$ & $-(0 / 0 \cdot 3)$ & $82(1 / 1 \cdot 2)$ & $106(2 / 1.9)$ & - \\
\hline Multiple myeloma $\ddagger$ & $602(1 / 0 \cdot 2)$ & $-(0 / 0 \cdot 1)$ & $-(0 / 0 \cdot 5)$ & $130(1 / 0 \cdot 8)$ & - \\
\hline Non-Hodgkin's lymphomał & $328(1 / 0 \cdot 3)$ & $-(0 / 0 \cdot 2)$ & $330(3 / 0 \cdot 9)$ & $286(4 / 1 \cdot 4)$ & $0 \cdot 2$ \\
\hline Ischaemic heart disease & $107(11 / 10 \cdot 3)$ & $13^{\star \star}(1 / 7 \cdot 5)$ & $99(42 / 42 \cdot 4)$ & $90(54 / 60 \cdot 2)$ & 0.43 \\
\hline Emphysema & $-(0 / 0 \cdot 2)$ & $-(0 / 0 \cdot 1)$ & $314(2 / 0 \cdot 6)$ & $198(2 / 1 \cdot 0)$ & - \\
\hline Asthma & $-(0 / 0 \cdot 1)$ & $-(0 / 0 \cdot 1)$ & $-(0 / 0 \cdot 3)$ & $-(0 / 0.5)$ & - \\
\hline Cirrhosis of liver & $326(3 / 0 \cdot 9)$ & $-(0 / 0.5)$ & $-(0 / 2 \cdot 0)$ & $88(3 / 3 \cdot 4)$ & - \\
\hline Nephritis & $-(0 / 0 \cdot 3)$ & $-(0 / 0 \cdot 2)$ & $114(1 / 0 \cdot 9)$ & $76(1 / 1 \cdot 3)$ & - \\
\hline
\end{tabular}

${ }^{\star} \mathrm{p}<0.05 ;{ }^{\star \star} \mathrm{p}<0.01$.

Cumulative exposure categories were derived by cumulatively multiplying the exposure index assigned to each job by time exposed at that level (see Stewart et al for a detailed explanation of the derivation).

+Derived from $\chi^{2}$ test for linear trend. ${ }^{8}$

†pecial categories created for this study.

\$ $\chi$ not computed if number of observed deaths $<5$. 
Table 6 SMRs and 95\% CIs for MM among white workers by exposure to selected groups of chemicals

\begin{tabular}{|c|c|c|c|c|c|c|}
\hline \multirow[b]{2}{*}{ Exposure category } & \multicolumn{3}{|l|}{ Men } & \multicolumn{3}{|c|}{ Women } \\
\hline & Obs & Person-years & $S M R(95 \% C I)$ & $O b s$ & Person-years & $S M R(95 \% C I)$ \\
\hline Any chemical & 12 & 222426 & $164(85-286)$ & 3 & 45359 & $218(45-636)$ \\
\hline Any solvent & 11 & 215076 & $156(78-280)$ & 3 & 44566 & $220(45-642)$ \\
\hline Mixed solvents & 11 & 214723 & $157(78-281)$ & 3 & 43960 & $223(46-653)$ \\
\hline Trichloroethylene & 5 & 152111 & $111(36-259)$ & 1 & 23634 & $130(3-722)$ \\
\hline Stoddard solvent & 5 & 146274 & $117(38-272)$ & 1 & 31960 & $114(3-633)$ \\
\hline Carbon tetrachloride & 7 & 142266 & $176(71-363)$ & 2 & 35290 & $200(25-721)$ \\
\hline Other chemicals & 4 & 93724 & $118(32-304)$ & 3 & 20463 & $386(80-1129)$ \\
\hline JP4/High octane aviation gasoline & 2 & 81265 & $106(13-382)$ & 0 & 13278 & - \\
\hline Freon & 3 & 53193 & $209(43-612)$ & 0 & 5088 & - \\
\hline Solder flux & 2 & 51555 & $162(20-585)$ & 0 & 4548 & - \\
\hline Isopropyl alcohol & $\overline{2}$ & 49915 & $165(20-596)$ & 0 & 5314 & - \\
\hline Zinc chromate & 0 & 44250 & - & 2 & 12886 & $681(82-2459)$ \\
\hline $1,1,1-$ Trichloroethane & 0 & 27223 & - & 2 & 1215 & $5660(685-20445)$ \\
\hline Acetone & 1 & 43719 & $81(2-452)$ & 2 & 8885 & $648(78-2342)$ \\
\hline Toluene & 2 & 32903 & $186(22-670)$ & 3 & 13373 & $835(172-2440)$ \\
\hline Methyl ethyl ketone & 1 & 32212 & $96(2-536)$ & 2 & 10042 & $904(109-3267)$ \\
\hline Methylene chloride & 4 & 22770 & $574(156-1469)$ & 0 & 3091 & - \\
\hline Metal fumes/dust & 0 & 25667 & - & 0 & 1512 & - \\
\hline Ortho-dichlorobenzene & 0 & 20829 & - & 0 & 2117 & - \\
\hline Perchloroethylene & 0 & 13281 & - & 2 & 2446 & $1705(206-6159)$ \\
\hline Known or suspected carcinogens & 1 & 15996 & $129(3-717)$ & 0 & 2291 & - \\
\hline Other alcohols & 1 & 14785 & $221(6-1231)$ & 0 & 1712 & - \\
\hline Chloroform & 0 & 2951 & - & 0 & 250 & - \\
\hline Styrene & 0 & 2812 & - & 0 & 937 & - \\
\hline Nitroglycerine & 0 & 1910 & - & 0 & 7 & - \\
\hline Silica & 0 & 2113 & - & 0 & 121 & - \\
\hline Xylene & 0 & 1837 & - & 0 & 444 & - \\
\hline Never any chemical & 2 & 47307 & $105(13-380)$ & 3 & 54039 & $258(53-753)$ \\
\hline Total cohort & 14 & 269733 & $152(83-255)$ & 6 & 99398 & $236(87-514)$ \\
\hline
\end{tabular}

Obs $=$ No of observed deaths due to multiple myeloma.

Person-years of follow up since 1 January 1953 or one year from first exposure to given chemical, whichever is later.

Table 7 SMRs and 95\% CIs for NHL among white workers by exposure to selected groups of chemicals

\begin{tabular}{|c|c|c|c|c|c|c|}
\hline \multirow[b]{2}{*}{ Exposure category } & \multicolumn{3}{|l|}{ Men } & \multicolumn{3}{|c|}{ Women } \\
\hline & Obs & Person-years & $S M R(95 \% C I)$ & Obs & Person-years & $S M R(95 \% C I)$ \\
\hline $\begin{array}{l}\text { Any chemical } \\
\text { Any solvent } \\
\text { Mixed solvents } \\
\text { Trichloroethylene } \\
\text { Stoddard solvent } \\
\text { Carbon tetrachloride } \\
\text { Other chemicals } \\
\text { JP4/High octane aviation gasoline } \\
\text { Freon } \\
\text { Solder flux } \\
\text { Isopropyl alcohol } \\
\text { Zinc chromate } \\
\text { 1,1,1-Trichloroethane } \\
\text { Acetone } \\
\text { Toluene } \\
\text { Methyl ethyl ketone } \\
\text { Methylene chloride } \\
\text { Metal fumes/dust } \\
\text { Ortho-dichlorobenzene } \\
\text { Perchloroethylene } \\
\text { Known or suspected carcinogens } \\
\text { Other alcohols } \\
\text { Chloroform } \\
\text { Styrene } \\
\text { Nitroglycerine } \\
\text { Silica } \\
\text { Xylene } \\
\text { Never any chemical } \\
\text { Total cohort }\end{array}$ & $\begin{array}{r}19 \\
18 \\
18 \\
10 \\
9 \\
9 \\
8 \\
5 \\
3 \\
4 \\
3 \\
4 \\
4 \\
3 \\
3 \\
3 \\
2 \\
0 \\
1 \\
2 \\
1 \\
2 \\
0 \\
0 \\
0 \\
0 \\
0 \\
3 \\
22\end{array}$ & $\begin{array}{r}222426 \\
215076 \\
214723 \\
152111 \\
146274 \\
142266 \\
93724 \\
81265 \\
53193 \\
51555 \\
49915 \\
44250 \\
27223 \\
43719 \\
32903 \\
32212 \\
22770 \\
25667 \\
20829 \\
13781 \\
15996 \\
14785 \\
2951 \\
2812 \\
1910 \\
2113 \\
1837 \\
47307 \\
269733\end{array}$ & $\begin{array}{c}123(74-192) \\
121(72-192) \\
122(72-192) \\
103(49-189) \\
97(44-184) \\
103(47-195) \\
118(50-228) \\
114(37-227) \\
95(20-279) \\
143(39-367) \\
110(23-322) \\
135(37-346) \\
188(51-482) \\
114(24-334) \\
129(27-378) \\
134(28-393) \\
134(16-484) \\
- \\
70(2-388) \\
190(23-685) \\
66(2-366) \\
203(25-734) \\
- \\
-\end{array}$ & $\begin{array}{l}7 \\
7 \\
7 \\
4 \\
3 \\
6 \\
4 \\
1 \\
0 \\
0 \\
0 \\
2 \\
0 \\
1 \\
2 \\
1 \\
0 \\
0 \\
1 \\
2 \\
0 \\
0 \\
0 \\
0 \\
0 \\
0 \\
0 \\
3 \\
10\end{array}$ & $\begin{array}{r}45359 \\
44566 \\
43960 \\
23634 \\
31960 \\
35290 \\
20463 \\
13278 \\
5008 \\
4548 \\
5314 \\
12886 \\
1215 \\
8885 \\
13373 \\
10042 \\
3091 \\
1512 \\
2117 \\
2446 \\
2291 \\
1712 \\
250 \\
937 \\
7 \\
121 \\
444 \\
54039 \\
99398\end{array}$ & $\begin{array}{l}279(112-575) \\
282(113-581) \\
286(115-560) \\
286(78-731) \\
185(38-540) \\
325(119-708) \\
283(77-723) \\
184(5-1022) \\
- \\
- \\
\overline{377}(46-1363) \\
\overline{183}(5-1018) \\
307(37-1108) \\
251(6-1400) \\
- \\
\overline{1008}(25-5616) \\
968(117-3496) \\
- \\
- \\
- \\
- \\
\overline{1} \\
212(102-390)\end{array}$ \\
\hline
\end{tabular}

Obs = No of observed deaths due to non-Hodgkin's lymphoma.

Person-years of follow up since 1 January 1953 or one year from first exposure to given chemical, whichever is later. 
chemical (table 6). The SMRs for several specific chemicals were raised, but they were based on small numbers and were usually not statistically significant. Significantly raised SMRs occurred among men exposed to methylene chloride (SMR 574, 95\% CI 156-1469), but no deaths from MM occurred among the 129 women ever exposed to this agent (only 0.09 would have been expected). Significantly raised SMRs were found among women exposed to $1,1,1$ trichloroethane (SMR 5660, 95\% CI 685-20 445), toluene $(S M R=835, C I=172-2440)$, methyl ethyl ketone (MEK) (SMR 904, 95\% CI 109-3267), and perchloroethylene (tetrachloroethylene) (SMR 1705, 95\% CI 206-6159), but not among men.

For all exposure categories in table 6 , the TG procedure ${ }^{9}$ was used to assess the significance of mortality differences among persons exposed to specific chemicals and persons in the cohort never exposed to any chemical while working at the base. In general, the results from the TG analyses for persons dying of multiple myeloma were consistent with the results from table 6 . The significant associations held among men exposed to methylene chloride $(n=4$, $\left.\chi^{2}=6 \cdot 8, p=0 \cdot 009\right)$ and women exposed to $1,1,1-$ trichloroethane $\left(\mathrm{n}=2, \chi^{2}=11.5, \mathrm{p}=0.001\right)$ or perchloroethylene $\left(\mathrm{n}=2, \chi^{2}=5.6, \mathrm{p}=0.018\right)$. The associations were not significant among women for multiple myeloma and exposures to toluene $\left(\mathrm{n}=3, \chi^{2}=3 \cdot 6, \mathrm{p}=0.058\right)$ or $\operatorname{MEK}(\mathrm{n}=2$, $\left.\chi^{2}=1 \cdot 6, p=0 \cdot 204\right)$. When the analysis was restricted to 20 years or more after first exposure, the association was statistically significant for multiple myeloma among men exposed to methylene chloride $\left(\mathrm{n}=2, \chi^{2}=4 \cdot 1, \mathrm{p}=0.043\right)$ and among women exposed to perchloroethylene $\left(n=2, \chi^{2}=4 \cdot 6\right.$, $\mathrm{p}=0.034)$, but not among women exposed to toluene $\left(\mathrm{n}=3, \chi^{2}=3 \cdot 2, \mathrm{p}=0.077\right)$.

\section{NON-HODGKIN'S LYMPHOMA}

For NHL, SMRs were greater than 100 for many chemicals and tended to be higher among women (table 7). For men, none of these excesses was statistically significant. For women, statistically significant associations were found among the total cohort (SMR 212, 95\% CI 102-390), persons ever exposed to any chemical (SMR 279, 95\% CI 112575), any solvent (SMR 282, 95\% CI 113-581), mixed solvents (SMR 286, 95\% CI 115-560), carbon tetrachloride (SMR 325, 95\% CI 119-708), and perchloroethylene (SMR 968, 95\% CI 117-3496). The association between perchloroethylene and NHL among white women was statistically significant in the TG analyses $\left(n=2, \chi^{2}=5 \cdot 2\right.$, $\mathrm{p}=0.022$ ). As well as the two perchloroethylene exposed cases, one other female case (reported in table 6 as "never exposed to any chemical") worked in a dry cleaning shop during non-Hill employment, where exposure to perchloroethylene may have occurred. When results for perchloroethyleneexposed men and women were combined, the overall SMR for NHL was 315 (95\% CI 86-609).

A review of work histories of persons dying from MM or NHL suggested that an unusual proportion of women developing these diseases may have worked in either or both of two fabric handling departments where "dope" (a substance used in fabric treatment) and solvents were used. Multiple myeloma was significantly raised among women employed in parachute repair (SMR 1717, 95\% CI 354-5018), and among those in fabric cleaning (SMR $1155,95 \%$ CI 140-4174), but no deaths were found from either cause among men employed in these shops. Non-Hodgkin's lymphoma was not significantly raised among men or women employed in these areas.

\section{Cancer of the biliary passages and liver}

For cancers of the biliary passages and liver, no significant associations occurred with exposure to any specific chemical (table not shown), although many of the SMRs were raised. Separate SMRs for cancer of the biliary passages and for liver cancer generally showed no significant excess risks. The TG analyses for liver cancer found no significant associations; the TG analyses for cancer of the biliary passages, however, showed significant associations for women exposed to zinc chromate $\left(n=2, \chi^{2}=3.96\right.$, $\mathrm{p}=0.04)$. This association persisted when latency was taken into consideration $\left(n=2, \chi^{2}=12.56\right.$, $\mathrm{p}<0.001)$.

\section{Asthma}

In the total cohort, the SMR for asthma among men was 205 (95\% CI 94-389). All of the male cases had been exposed to some chemical while employed at Hill Air Force Base. The SMRs among men were raised for several of the exposures, especially for Stoddard solvent (SMR 301, 95\% CI 110-655), carbon tetrachloride (SMR 328, 95\% CI 120-714), and methylene chloride (SMR 932, 95\% CI 1922723). For male asthma cases, the TG analyses showed a significant association only with exposure to methylene chloride $\left(\mathrm{n}=3, \chi^{2}=8.43, \mathrm{p}=0.004\right)$. All three of these cases had at least five years of exposure to methylene chloride. Data to evaluate risk when latency (at least 20 years since first exposed or first employed) was considered were inadequate $(\mathrm{n}=1)$. Among women the SMR for asthma was $168(95 \%$ CI $35-490)$, but none of the three cases had exposure to any chemical.

\section{ANALYSIS OF SPECIFIC CHEMICALS \\ Mixed solvents}

We evaluated the SMRs for selected causes of death among white men and women, by cumulative exposure to mixed solvents. The SMRs were sig- 
nificantly raised for asthma among men (SMR 240, 95\% CI 104-473), and for NHL among women (SMR 286, 95\% CI 115-560) (table 7). Significant deficits were found among men for all causes of death (SMR 94, 95\% CI 90-98) and, among women, for all causes of death (SMR 90, 95\% CI 80-99), and all cancer (SMR 75, 95\% CI 58-96). Among men, significant upward trends occurred across cumulative exposure categories for pancreatic cancer, particularly 20 years after first exposure $(n=17$, $\left.\chi^{2}=2 \cdot 47\right)$, and for emphysema $\left(\mathrm{n}=44, \chi^{2}=2 \cdot 29\right)$. Insufficient numbers of cases existed among women in most subcategories to allow analysis by cumulative exposure, although all three cases of MM had more than five years of exposure.

\section{Other selected chemicals}

We further examined individual causes of death by chemical exposure and found many significant deficits for various causes of death for exposures to specific chemicals. Significantly raised SMRs occurred for men exposed to xylene (cancer of the central nervous system, SMR 1436, 95\% CI 174-5184); and for women exposed to JP4/high octane aviation gasoline (cancer of buccal cavity and pharynx, SMR 853, 95\% CI 103-3079), freon (breast cancer, SMR 309, 95\% CI 124-637), solder flux (breast cancer, SMR 310, 95\% CI 113-675), and isopropyl alcohol (breast cancer, SMR 312, 95\% CI 125-643). The excesses of breast cancer among women exposed to freon, solder flux, and isopropyl alcohol were not independent: six out of seven of these cases had exposure to all three chemicals.

The TG analyses of breast cancer showed highly significant associations with exposures to isopropyl alcohol $\left(\mathrm{n}=7, \chi^{2}=17.37, \mathrm{p}<0.001\right)$, freon $\left(\mathrm{n}=7, \chi^{2}=15.37, \mathrm{p}<0.001\right)$, solder flux $(\mathrm{n}=6$, $\left.\chi^{2}=15.14, p<0.001\right)$, and other alcohols $(\mathrm{n}=2$, $\left.\chi^{2}=10 \cdot 24, \mathrm{p}=0 \cdot 001\right)$. Also, breast cancer was significantly raised among women exposed to methylene chloride $\left(\mathrm{n}=3, \chi^{2}=6 \cdot 12, \mathrm{p}=0.01\right)$.

\section{Discussion}

Over the years many chemicals have been used at this base in the repair and maintenance of aircraft. These include chlorinated hydrocarbons (trichloroethylene, perchloroethylene, chloroform, 1,1,1-trichloroethane, methylene chloride, ortho-dichlorobenzene, and freon), aromatic hydrocarbons (toluene, xylene), aliphatics (isopropyl alcohol, and other alcohols), and other compounds such as carbon tetrachloride, solder flux, zinc chromate, silica, and high octane fuels. Exposure of man to these chemicals is of concern because several cause cancer in animals (chloroform, methylene chloride, isopropyl alcohol, silica, perchloroethylene, and trichloroethylene). ${ }^{13}$ Data, however, are lacking or insufficient to draw definite conclusions about their effects in man. ${ }^{13}$ This study of 14457 civilian workers at an air force aircraft maintenance facility was initiated because this population provided the opportunity to obtain important epidemiological information on trichloroethylene and other chemicals widely used in industry, and because of preliminary evidence indicating that these workers might be experiencing a high proportion of deaths due to MM. ${ }^{1}$ Experimental studies of TCE provided limited evidence for carcinogenicity in animals. ${ }^{13}$

Compared with other epidemiological studies of cohorts exposed to solvents, the study is large and is one of the few to present results for both sexes. Several limitations need to be considered, however, in interpreting the results. Many SMRs were computed because the cohort had potential exposure to a large number of chemicals. Subgroup analyses were done by sex, by specific chemical, by latency, and by duration of exposure or level of exposure. Few deaths occurred from most diseases showing raised SMRs. Although subgroup analysis is an important step in establishing new links between diseases and specific exposures, it also introduces chance results due to the increase in the number of comparisons and a decrease in the size of the subgroups being analysed. Due to the multiple statistical comparisons, some of the significantly high and low SMRs probably reflect chance observations.$^{14}$ Also, overlap of chemical use among defined exposure groups was considerable, with most workers exposed to more than one chemical. This makes it difficult to relate excess risks to specific chemical exposures. Many of the solvents were used interchangeably and some may have been contaminated with other chemicals. Clustering of disease excesses also occurred for certain exposure categories-for example, men exposed to methylene chloride had excess risks for MM and cancer of the biliary passage, bladder cancer, and asthma. Furthermore, some chemicals under study are metabolised into other chemicals.

Smoking histories were not available. For smoking to confound associations, however, not only must it have been a risk factor for the disease of interest, but the proportion who smoked must differ between the exposed and unexposed members of the cohort. Evidence to date does not indicate a direct relation between smoking and multiple myeloma, nonHodgkin's lymphoma, or cancer of the biliary passages and liver. ${ }^{15}$ Other investigators have seldom found that the proportion of smokers differed substantially between exposed and unexposed subjects, ${ }^{1617}$ and we have no reason to suspect a difference in the current study. The study also lacked information on other factors of lifestyle, such as religion and consumption of alcohol.

Statistical results were generally consistent whether based on SMRs or the life table TG 
procedure. ${ }^{9}$ Both methods adjust for differences in age and calendar year, but the second procedure is based on comparisons within the cohort of workers. The first method is more easily interpreted, however, as it provides estimates of relative risk.

Persons living in Utah have lower death rates than the United States population, ${ }^{18}$ largely attributable to differences in lifestyle due to the influence of the Church of Jesus Christ of Latter Day Saints (Mormons). ${ }^{19}$ Therefore, we used death rates from the state of Utah to generate expected numbers of deaths in computations of SMRs. Comparison with Utah death rates provided a comparison that was culturally closer to the cohort than use of United States population death rates, with only a slight loss of stability. Additional analyses (not presented), with the United States population as the standard, produced slightly lower SMRs, but were consistent with the results shown in this paper. Use of national or state death rates as the standard is generally thought to underestimate the true underlying relative risks in occupational mortality studies because of the healthy worker effect. ${ }^{20}$

To rule out cultural and behavioural differences between the workers in the cohort and the population of Utah, within cohort analyses (TG method) provided a closer possible cultural group for comparison by utilising an employed population as the comparison group. Because of few cohort members in the never exposed group, however, this last analysis suffered from problems of stability. Also, the proportion of never exposed workers who were in salaried rather than wage grade jobs was $61 \%$ compared with less than $1 \%$ of exposed workers, indicating that the TG analyses did not compare groups of exactly similar socioeconomic state.

These limitations do not invalidate results from this study. On the contrary, it possessed strengths that provided unique opportunities to evaluate mortality risks associated with exposures found in this facility. With over 14000 study subjects followed up for over 25 years, this was a large occupational cohort. The study included an exposure assessment component that was more detailed than typically found in epidemiological studies. Although misclassification of exposures to specific substances undoubtedly occurred, the degree of misclassification associated with this approach is likely to be substantially less than that from analyses based only on occupational titles. Consistency of findings using national, state, and unexposed worker populations as comparison groups decreases the likelihood that results are due to chance.

\section{DISEASES}

When compared with the general mortality experience of the Utah population, mortality in the study cohort was significantly raised for $M M$ and
NHL among white women and for asthma and cancer of the biliary passages and liver among white men. The MM excess was of particular interest as a preliminary investigation of 67 cancer deaths, identified by workers and air force officials, had shown a raised number (four) of multiple myelomas. Significant deficits occurred for several causes. More detailed evaluation of mortality patterns by specific chemical exposures uncovered a number of associations. Small numbers for most chemicals and overlapping exposures, however, complicate interpretation.

Significantly raised SMRs for MM occurred among women exposed to perchloroethylene, 1,1,1trichloroethane, toluene, and MEK, and among men exposed to methylene chloride, all based on fewer than five deaths. Non-significant increases, however, were associated with exposures to some other chemicals and were also seen among women never exposed to chemicals. All three cases of MM among women exposed to chemicals worked in fabric handling operations (two worked specifically on parachute repair), where they may have had contact with carbon tetrachloride, perchloroethylene, trichloroethylene, and possibly toluene, Stoddard solvent, "dope" (a stiffening agent for cloth), or nitrocellulose paint. Specific identification of the chemicals used in these products could not be made. Two of these cases had also been exposed to 1,1,1-trichloroethane, toluene, methyl ethyl ketone, and zinc chromate in other work areas. One of the women classified as having no exposure to chemicals had worked in a dry cleaning shop before coming to work at the base.

A carcinogenesis bioassay study found significant increases in mammary tumours in rats and lung and liver tumours in mice given methylene chloride by inhalation. ${ }^{21}$ The excess of $M M$ among white men exposed to methylene chloride has not been found in other epidemiological studies. A survey of workers exposed to methylene chloride in the production of photographic chemicals noted an excess for pancreatic cancer (eight observed deaths $v 3.2$ expected) but not for $M M^{22}{ }^{23}$ No such excess for pancreatic cancer was noted for exposures to methylene chloride in the current study, although a significant trend in SMRs was found across cumulative exposure categories for men exposed to mixed solvents. Ott et al ${ }^{24} 25$ studied synthetic fibre production workers exposed to methylene chloride in South Carolina. Based on a total of 54 deaths, no excess mortality was seen for any cause of death.

An excess of NHL was seen among women exposed to perchloroethylene, based on two deaths (one in the parachute repair section at the base and the other, who may have also been exposed to perchloroethylene as a laundry and dry cleaning worker outside of the base, as an aircraft mechanic). A recent inhalation carcinogenesis bioassay showed 
increases in hepatocellular carcinomas in mice and mononuclear cell leukaemia in male rats after exposure to perchloroethylene. ${ }^{26}$ Epidemiological evaluations are, however, inconsistent. Studies of dry cleaners exposed to various solvents including perchloroethylene, Stoddard solvent, and carbon tetrachloride have shown significant excesses for the various cancers-namely, liver among women only ${ }^{26 a}$; cervix uteri and oesophagus, with slight excesses for cancers of the bladder and the lymphatic and haematopoietic system ${ }^{27}$; urinary tract ${ }^{28}$; kidney, and genital sites with non-significant increases for lymphosarcoma and bladder cancer ${ }^{29}$; lung and kidney ${ }^{30}$; and leukaemia and lymphoma in men exposed to 1,1,2,2-tetrachloroethane and dry cleaning solvents. $^{31}$

Other studies have reported associations with NHL among chemists ${ }^{32}$ and farmers. ${ }^{34-37}$ In Sweden, Hardell et al ${ }^{38}$ related malignant lymphoma (Hodgkin's disease and NHL) to phenoxy acids, chlorophenols, and organic solvents (especially benzene, trichloroethylene, perchloroethylene, and styrene), and Persson et $a l^{39}$ found an association between NHL and solvents, phenoxy acids, and creosote.

Excess risk of liver cancer among women, but not among men, has been associated with exposure to solvent, using data from the Finnish Cancer Registry. ${ }^{4041}$ Other studies have found excesses of liver cancer for broadly defined occupational groups such as metal workers, ${ }^{42}$ coast guard marine inspectors, ${ }^{43}$ and agricultural workers. ${ }^{44}$ Krain $^{45}$ noted an excess of bile duct cancers among workers in the aircraft and other industries. We were unable to relate the excess mortality from cancer of biliary passages and liver to any particular chemical exposure. In laboratory animals, liver tumours may be produced by exposures to trichloroethylene ${ }^{46}{ }^{47}$ perchloroethylene, ${ }^{26}$ or chloroform. ${ }^{489}$ It was difficult to evaluate liver cancer, however, because there were few cases and because it is difficult to distinguish metastatic cancers from primary cancers using only information from death certificates. Percy et $a l^{50}$ found that the proportion of hospital diagnoses of liver cancer also noted on the death certificate was around $50 \%$, and about three quarters of death certificates with a mention of liver cancer could be confirmed by hospital records. For comparison, these proportions for MM were $97 \%$ and $98 \%$ respectively.

The statistically significant SMR for asthma among men exposed to methylene chloride in this study was also unexpected. Methylene chloride is metabolised to carbon monoxide, which results in increased carboxyhaemoglobin concentrations in man..$^{51}$ As the three deaths from asthma occurred many years after last exposure, however, it is unlikely that methylene chloride was causally related to this excess. Occupational asthma has been described among men employed as spray painters, presumably due to exposure to isocyanate, ${ }^{52}$ but there was no suggestion of exposure to isocyanate among those asthma cases in our study.

We found significant SMRs for breast cancer among women exposed to freon, solder flux, and isopropyl alcohol. These chemicals were also significantly associated with breast cancer in the TG analysis, as were methylene chloride and other alcohols. Several recent studies have reported a raised risk of breast cancer among women who drank alcoholic beverages, ${ }^{53-58}$ although a causal association remains uncertain and may be confounded by other risk factors. ${ }^{59}$ Alcoholic beverages contain ethyl alcohol, which is close in chemical structure to some of the alcohols used by the cohort. Teta $e t$ al ${ }^{60}$ have reported an excess risk of breast cancer among cosmetologists. The excess of breast cancer in women exposed to methylene chloride is intriguing, given the ability of this agent to produce mammary tumours in rats. ${ }^{21}$ Breast cancer is influenced by factors of lifestyle and socioeconomic state ${ }^{61}$ so that it is more appropriate to use the TG analysis, which is based on the mortality experience of other women employed at the base as the standard for comparison. It is interesting that SMRs for bladder cancer among men in the current study were raised, though not significantly, after exposure to the same chemicals.

Recent studies of incidence of testicular cancer among United States navy personnel have implied an excess risk among aircraft repair workers ${ }^{62}{ }^{63}$ It was suggested that dimethylformamide (DMF) may be the causal agent. There was no use of DMF at the base; nor was there any excess mortality from testicular cancer.

\section{EXPOSURES}

The solvents used at the base were primarily chlorinated hydrocarbons (chloroform, ortho-dichlorobenzene, freon, methylene chloride, perchloroethylene, 1,1,1-trichloroethane, trichloroethylene), aromatic hydrocarbons (toluene, xylene), alcohols (isopropyl alcohol, other alcohols), and carbon tetrachloride. Perchloroethylene is similar to trichloroethylene in chemical structure, and is metabolised to trichloroethylene.$^{64}$ Several of the solvents under question are fat soluble and are stored in fatty tissue. ${ }^{65}$ As well as concerns raised by bioassay studies of carcinogenesis, a major toxic effect of these solvents has been depression of the central nervous system. ${ }^{66}{ }^{67}$ A raised SMR for cancer of the central nervous system among men exposed to xylene, which has acute toxic effects on the system, has not, to our knowledge, been previously reported.

Several approaches were adopted to evaluate mortality risks associated with exposure to TCE. No overall association was found between exposure to 
TCE and any cause of death within this study. This is consistent with other cohort studies of TCE exposed' workers. ${ }^{68}{ }^{69}$ Although an overall deficit of deaths from emphysema among men exposed to TCE was found (SMR 83, 95\% CI 55-121), we cannot explain the significant upward trend of the SMRs by cumulative exposure to TCE seen in table 4 . Two other epidemiological studies on case series of liver cancers ${ }^{70}{ }^{71}$ found no association with TCE exposed jobs. Experimental studies of TCE provide limited evidence for carcinogenicity in animals. ${ }^{13}$ Methyl chloroform (1,1,1-trichloroethane), which largely replaced TCE in the 1970 s as the primary solvent used at the base, is generally not considered to be carcinogenic. ${ }^{7273}$

A considerable effort was put into estimating potential exposures from inhalation in this study, particularly to TCE and mixed solvents. It was not possible to evaluate potential dermal exposures, which could have led to misclassification of study subjects. Also, most of the cohort who had exposure to TCE were exposed to comparatively low concentrations of this chemical. For other chemicals, estimates of exposure levels, either from inhalation or dermal absorption, could not be made. Although we think that the sensitivity was high for assigning chemical exposure to jobs, we are less certain regarding the specificity of this approach-that is, it seems likely that some jobs with certain chemical exposures were not recognised. When exposure to solvents seemed likely, but uncertainty existed in assigning the specific solvents used, the project industrial hygienists (JSL, DEM) assigned the category of mixed solvents. Thus some persons classified as nonexposed to a particular substance may have actually had such an exposure. Such misclassification of exposure would moderate exposure response gradients. ${ }^{74}$

\section{Conclusions}

Although this is the largest study to date of workers exposed to TCE, no significant or persuasive relations were found between various measures of exposure to TCE and the risk of any specific malignancy. These results are consistent with other epidemiological studies of workers exposed to TCE. Because of the few deaths for many types of cancer and the low levels of exposure to TCE, it is only possible to suggest, at this time, that occupational exposure to TCE probably does not pose a strong carcinogenic risk for man.

Given the original concern regarding excess deaths from $M M$ among workers at the base we were not surprised to find raised SMRs for MM and NHL. These SMRs were associated with various chemical exposures and could not be specifically ascribed to any particular substance. The most consistent associations were seen for two specific work areas; statistically significant SMRs for MM among women (SMR 1717, 95\% CI 354-5020) and non-significant raised SMRs for NHL in both sexes were seen for workers in departments concerned with fabric cleaning and repair of parachutes. Exposures in these departments included various solvents as well as a "dope" of unknown formulation used as a stiffening agent for fabric. With regard to specific exposures and the risks of MM, statistically significant SMRs were seen among women exposed to perchloroethylene (SMR 1705, 95\% CI 206-6159), toluene (SMR 835, 95\% CI 172-2440), methyl ethyl ketone (SMR 904, 95\% CI 109-3267), and 1,1,1-trichloroethane (SMR $5660,95 \%$ CI $685-20445)$. For NHL, no statistically significant associations were noted for men, whereas among women, significant associations occurred with exposure to any chemical (SMR 279, 95\% CI 112-575), any solvent (SMR 282, 95\% CI 113-581), mixed solvents (SMR 286, 95\% CI 115560 ), carbon tetrachloride (SMR 325, 95\% CI 119 708), and perchloroethylene (SMR 968, 95\% CI 117-3496). The few cases, multiple and overlapping exposures, differences in SMRs between the sexes, and multiple non-significant associations with many other chemicals complicate any attempt to relate the mortality excesses for $M M$ and NHL to specific exposures. Further complicating interpretations are the raised SMRs for both of these tumours among women never exposed to chemicals at the base. None the less, the associations between these tumours and chemicals such as carbon tetrachloride and perchloroethylene that cause cancer in laboratory animals, plus similarities to other epidemiological investigations that have noted associations between various solvent exposures and risks of lymphatic and haematopoietic neoplasms, provide a biological plausibility which, we believe, does not allow these findings to be clearly dismissed as chance occurrences.

Exposure assessment in this cohort also allowed exposure specific assessment of risks of cancer sites that were not in excess in the total cohort. Here, even more than in the case of $\mathrm{MM}$ and NHL, caution is needed to avoid overinterpretation of what may be chance observations. Perhaps the most provocative finding, however, was the series of associations with excess breast cancer, a cancer site not usually associated with occupational exposures. Included were significantly raised SMRs among women exposed to isopropyl alcohol (SMR 312, 95\% CI 125-642), freon (SMR 309, 95\% CI 124-638), solder flux (SMR 310, 95\% 114-674), and non-significant associations with methylene chloride (SMR 204, 95\% CI 42-597) and other alcohols (SMR 271, 95\% CI 33-980). Increasing employment of women in blue collar jobs indicates the need for further evaluation of these associations in studies that will allow assessment as to whether they aie related to job 
exposures or to factors of lifestyle associated with women employed in these jobs.

The conclusions, recommendations, or other views expressed herein are those of the authors and do not necessarily reflect the official views of the United States Air Force, Department of Defence, or the American Federation of Government Employees. We thank our colleagues at the National Cancer Institute for their thoughtful criticisms of this report.

Requests for reprints to: Robert Spirtas, Dr P H CEB, CPR, NICHD, Executive Plaza North, Room 607, Bethesda, MD 20892, USA.

1 US House of Representatives. Hearings before the Subcommittee on Investigations of the Committee on Post Office and Civil Service. Washington: 1979 (No 96-28(50-747), 3,4, and 10 April.)

2 US Senate. Hearing before the Committee on Labor and Human Resources. Washington: 1981 (82-945, 11 July.)

3 National Center for Health Statistics. User's manual: the national death index. Hyattsuilk, MD, 1981 (DHSS publ No(PHS) 811148.)

4 US Department of Health, Education, and Welfare. Eighth revision, international classification of diseases, adapted for use in the United States. Washington, DC, 1976 (Public Health Service publ No 1693.)

5 Stewart PA, Lee JS, Marano DE, Spirtas R, Forbes CD, Blair A. Retrospective cohort mortality study of workers at an aircraft maintenance facility. II Exposures and their assessment. $(B r J$ Ind Med 1991;48:531-37.

6 Marsh GM, Preininger M. OCMAP: A user-oriented occupational cohort mortality analysis program. American Statistician 1980;34:245.

7 Bailar JC, III, Ederer F. Significant factors for ratio of a Poisson variable to its expectation. Biometrics 1964;20:639-43.

8 Breslow NE, Lubin JH, Marek P, Langholz B. Multiplicative models and cohort analysis. Journal of the American Statistical Association 1983;78:1-12.

9 Thomas DG, Gart JJ. Stratified trend and homogeneity analyses of proportions and life table data. Computers and Biomedical Research 1983;16:116-26.

10 US Bureau of the Census. 1970 Census of population, characteristics of the population, Utah Washington; US Government Printing Office, 1973;1:(part 46) table 45.

11 Torkelson TR, Rowe VK. Halogenated aliphatic hydrocarbons containing chlorine, bromine, and iodine. In: Clayton GD, Clayton FE, eds. Patty's industrial hygiene and toxicology, 3rd revised edition. New York: John Wiley and Sons, 1981:2B:3433-601.

12 Mason TJ, Fraumeni JF, Jr, Hoover R, Blot WJ. An atlas of mortality from selected diseases. Washington, DC, 1981 (NIH publ No 81-2397.)

13 International Agency for Research on Cancer. Monographs on the evaluation of carcinogenic risks to humans. Overall evaluations of carcinogenicity: an updating of IARC monographs. Vols 1 to 42. Lyon: IARC, 1987.

14 Colton T. Statistics in medicine. Boston: Little, Brown and Co. 1974:303-4.

15 US Department of Health, Education, and Welfare. Smoking and Health: a report of the Surgeon General. 1979; DHEW Publication No (PHS) 79-50066.

16 Blair A, Hoar S, Walrath J. Comparison of crude and smokingadjusted standardised mortality ratios. J Occup Med 1985; 27:881-4.

17 Siemiatycki J, Wacholder S, DeWar R, et al. Smoking and degree of occupational exposure: Are internal analyses in cohort studies likely to be confounded by smoking status? $\mathrm{Am}$ $J$ Ind Med 1988;13:59-70.

18 Lyon JL, Gardner JW, Klauber MR, Smart CR. Low cancer incidence and mortality in Utah. Cancer 1977;39:2608-18.

19 Lyon JL, Klauber MR, Gardner JW, Smart CR. Cancer incidence in Mormons and non-Mormons in Utah, 19661970. New Engl J Med 1976;294:129-33.
20 McMichael AJ. Standardised mortality ratios and the "healthy worker effect": Scratching beneath the surface. J Occup Med 1976;18:165-8.

21 National Toxicology Program. NTP technical report on the toxicology and carcinogenesis studies of dichloromethane (methylene chloride) (CAS No 75-09-2) in F344/n rats and B6C3F1 mice (inhalation studies). Research Triangle Park: US Department of Health and Human Services, 1985 (NIH publ No 85-252; NTP-85-024.)

22 Friedlander BR, Hearne T, Hall S. Epidemiological investigation of employees chronically exposed to methylene chloride. J Occup Med 1978;20:657-66.

23 Hearne FT, Grose F, Pifer JW, Friedlander BR, Raleigh RL. Methylene chloride mortality study: Dose-response characterisation and animal model comparison. J Occup Med 1987;29:217-28.

24 Ott MG, Skory LK, Holder BB, Bronson JM, Williams PR. Health evaluation of employees occupationally exposed to methylene chloride. General study design and environmental considerations. Scand J Work Environ Health 1983;9:1-7.

25 Ott MG, Skory LK, Holder BB, Bronson JM, Williams PR. Health evaluation of employees occupationally exposed to methylene chloride. Mortality. Scand $J$ Work Environ Health 1983;9:8-16.

26 National Toxicology Program. Toxicology and carcinogenesis studies of tetrachloroethylene (perchloroethylene) (CAS No $127-18-4$ ) in $F 344 / N$ rats and B6C3FI mice inhalation studies). Research Triangle Park: US Department of Health and Human Services, 1986. (Tech rep ser No 311 ; NIH publ No 86-2567.)

26a Lynge E, Thygesen L. Primary liver cancer among women in laundry and dry-cleaning work in Denmark. Scand J Work Environ Health 1990;16:105-12.

27 Blair A, Stewart PA, Tolbert P, et al. Cancer and other causes of death among a cohort of dry cleaners. $\mathrm{Br} J$ Ind Med 1990; 47:162-8.

28 Brown D, Kaplan SD. Retrospective cohort study of dry cleaner workers using perchloroethylene. J Occup Med 1987;29: $535-41$

29 Katz RM, Jowett D. Female laundry and dry cleaning workers in Wisconsin: A mortality analysis. Am J Public Health 1981; 71:305-7.

30 Duh RW, Asal NR. Mortality among laundry and dry cleaning workers in Oklahoma. Am J Public Health 1984;74:1278-80.

31 Norman JE, Robinette CD, Fraumeni JF. The mortality experience of Army World War II chemical processing companies. J Occup Med 1981;23:818-22.

32 Li FP, Fraumeni JF, Mantel N, Miller RW. Cancer Mortality among chemists. JNCI 1969;43:1159-64.

33 Searle CE, Waterhouse JAH, Henman BA, et al. Epidemiological study of the mortality of British chemists. $B r$ J Cancer 1978;38:192-3.

34 Schumacher MC. Farming occupations and mortality from nonHodgkin's lymphoma in Utah: A case-control study. J Occup Med 1985;27:580-4.

35 Cantor KP. Farming and mortality from non-Hodgkin's lymphoma: A case-control study. Int J Cancer 1982;29:239-47.

36 Hoar SK, Blair A, Holmes FF, et al. Agricultural herbicide use and risk of lymphoma and soft-tissue sarcoma. JAMA 1986; 256:1141-7.

37 Pearce NE, Sheppard RA, Smith AH, Teague CA. Non-Hodgkin's lymphoma and farming: An expanded case-control study. Int J Cancer 1987;39:155-61.

38 Hardell L, Ericksson M, Lenner P, Lundgren E. Malignant lymphoma and exposure to chemicals, especially organic solvents, chlorophenols and phenoxy acids. A case-control study. Br J Cancer 1981;43:169-76.

39 Persson B, Dahlander A-M, Fredrikson M, Noorlind Brage H, Ohlson C-G, Axelson O. Malignant lymphomas and occupational exposures. $\mathrm{Br} J$ Ind Med 1989;46:516-20.

40 Hernberg S, Korkala ML, Asikainen U, Riala R. Primary liver cancer and exposure to solvents. Int Arch Occup Environ Health 1984;54:147-53.

41 Hernberg S, Kauppinen T, Riala R, Korkala M-L, Asikainen U. Increased risk for primary liver cancer among women exposed to solvents. Scand J Work Environ Health 1988;14:356-65.

42 Houten L, Sonnesso G. Occupational exposure and cancer of the liver. Arch Environ Health 1980;35:51-3.

43 Blair A, Haas $\Gamma$, Prosser R, et al. Mortality among United States Coast Guard marine inspectors. Arch Environ Health 1989; 44:150-6.

44 Stemhagen A, Slade J, Altman R, Bill J. Occupational risk factors and liver cancer: A retrospective case-control study of 
primary liver cancer in New Jersey. Am $J$ Epidemiol 1983;117:443-54

45 Krain LS. Gallbladder and extrahepatic bile duct carcinoma. Analysis of 1808 cases. Geriatrics 1972;27:111-7.

46 National Cancer Institute. Carcinogenesis bioassay of trichloroethylene. Bethesda, MD: NCI, 1976. (NCI-CG-TR-2.)

47 National Toxicology Program. NTP technical report on the carcinogenesis bioassay of trichloroethylene in F344/N rats and B6C3F1 mice (Gavage study). Research Triangle Park: US Department of Health and Human Services. 1982;32:15. (NTP tech rep No 243.)

48 Eschenbrenner $\mathrm{AB}$. Induction of hepatomas in mice by repeated oral administration of chloroform, with observations on sex differences. $J$ Natl Cancer Inst 1945;5:251-5.

49 National Cancer Institute. Report on the carcinogenesis bioassay of chloroform. Carcinogenesis program, division of cancer cause and prevention. Bethesda, MD:NCI, 1976.

50 Percy C, Stanek E, Gloeckler L. Accuracy of cancer death certificates and its effect on cancer mortality statistics. $\mathrm{Am} \mathrm{J}$ Public Health 1981;71:242-50.

51 Stewart RD, Fisher TN, Hosko MJ, Peterson JE, Baretta ED, Dodd HC. Experimental human exposure to methylene chloride. Arch Environ Health 1972;25:342-8.

52 Seguin P, Allard A, Cartier A, Malo JL. Prevalence of occupational asthma in spray painters exposed to several types of isocyanates, including polymethylene polyphenylisocyanate. J Occup Med 1987;29:340-4.

53 Hiatt R, Klatsky AL, Armstrong MA. Alcohol consumption and the risk of breast cancer in a prepaid health plan. Cancer Res 1988;48:2284-7.

54 Schatzkin A, Jones DY, Hoover RM, et al. Alcohol consumption and breast cancer in the epidemiologic follow-up study of the first National Health and Nutrition Examination Survey. $N$ Engl J Med 1987;316:1169-73.

55 Willett WC, Stampfer MJ, Colditz GA, Rosner BA, Hennekens $\mathrm{CH}$, Speizer FE. Moderate alcohol consumption and the risk of breast cancer. N Engl J Med 1987;316:1174-80.

56 Williams RR, Horm JW. Association of cancer sites with tobacco and alcohol consumption and socioeconomic status of patients: Interview study from the Third National Cancer Survey. INCI 1977;58:525-47.

57 Rosenberg L, Slone D, Shapiro S, et al. Breast cancer and alcoholic-beverage consumption. Lancet 1982; i:267-71.

58 Begg CB, Walker AM, Wessen B, Zelen M. Alcohol consumption and breast cancer (letter). Lancet 1983;i:293-4.

59 Harris RE, Wynder EL. Breast cancer and alcohol consumption: A study in weak associations. $J A M A$ 1988;259:2867-71.
60 Teta MJ, Walrath J, Meigs JW, Flannery JT. Cancer incidence among cosmetologists. J Natl Cancer Inst 1984;72:1051-7.

61 Helmrich SP, Shapiro S, Rosenberg L, et al. Risk factors for breast cancer. Am J Epidemiol 1983;117:35-45.

62 Ducatman AM, Conwill DE, Crawl J. Germ cell tumors of the testicle among aircraft repairmen. J Urol 1986;136:834-6.

63 Garland FC, Gorham ED, Garland CF, Ducatman AM. Testicular cancer in US Navy personnel. Am J Epidemiol $1988 ; 127: 411-4$.

64 Vogel TM, McCarty PL. Biotransformation of tetrachloroethylene to trichloroethylene, dichloroethylene, vinyl chloride, and carbon dioxide under methanogenic conditions. $A p p l$ Environ Microbiol 1985;49:1080-3.

65 McConnel G, Ferguson DM, Pearson CR. Chlorinated hydrocarbons and the environment. Endeavour 1975;34: 13-18.

66 US Department of Health and Human Services. Current intelligence bulletin 48. Cincinnati, $\mathrm{OH}, 1987$. (DHHS (NIOSH) publ No 87-104.)

67 Angerer J. Biological monitoring of workers exposed to organic solvents-Past and present. Scand J Work Environ Health 1985;11(suppl 1):45-52.

68 Axelson O, Andersson K, Hogstedt C, Holmberg B, Molina G, deVerdier A. A cohort study on trichloroethylene exposure and cancer mortality. J Occup Med 1978;20:194-6.

69 Tola S, Vilhunen R, Jarvinen E, Korkala ML. A cohort study on workers exposed to trichloroethylene. J Occup Med 1980; 22:737-40.

70 Novotna E, David A, Malek B. An epidemiologic study on hepatic tumor incidence in subjects working with trichloroethylene. Pracovni Lekarstvi 1979;4:121-3.

71 Paddle GM. Incidence of liver cancer and trichloroethylene manufacture: Joint study by industry and a cancer registry. $\mathrm{Br}$ Med J 1983;286:846.

72 National Cancer Institute. Bioassay of 1,1,1-trichloroethane for possible carcinogenicity. Bethesda, MD: NCI, 1977. (NCICG-TR-3.

73 National Institute for Occupational Safety and Health. Criteria for a recommended standard ... occupational exposure to 1,1,1trichloroethane perchloroethylene). Cincinnati: NIOSH, 1976. (DHEW (NIOSH) publ No 76-185.)

74 Copeland KT, Checkoway H, McMichael AJ, et al. Bias due to misclassification in the estimation of relative risk. $A m J$ Epidemiol 1977;105:488-95.

Accepted 7 January 1991

\section{Correspondence and editorials}

The British Journal of Industrial Medicine welcomes correspondence relating to any of the material appearing in the journal. Results from preliminary or small scale studies may also be published in the correspondence column if this seems appropriate. Letters should be not more than 500 words in length and contain a minimum of references. Table and figures should be kept to an absolute minimum. Letters are accepted on the understanding that they may be subject to editorial revision and shortening.

The journal now also publishes editorials which are normally specially commissioned. The Editor welcomes suggestions regarding suitable topics; those wishing to submit an editorial, however, should do so only after discussion with the Editor. 